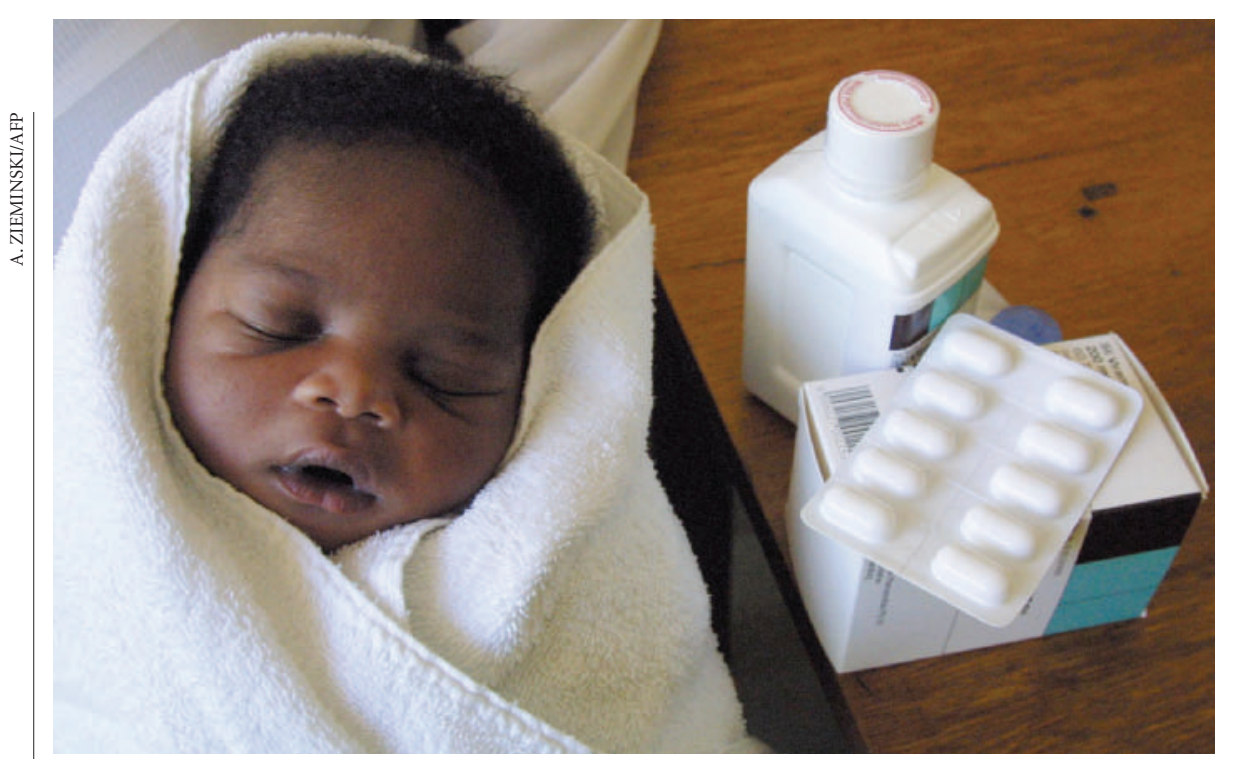

Bitter pill: an antiretroviral that protects babies can leave their mothers resistant to treatment.

\title{
Health minister ignites row over drugs for HIV mothers
}

\section{Erika Check, Bangkok}

Doctors should provide more treatment for pregnant women with HIV — not less. So argued scientists last week, after a controversial statement by the South African health minister at the XV International AIDS Conference in Bangkok.

The row focused on studies of a treatment that reduces the risk of women transmitting HIV to their babies during childbirth; some 700,000 children were born with HIV last year. Scientists already know that the treatment - a single dose of a drug called nevirapine (sold as Viramune) given to the mother during labour - can encourage drug-resistant viruses to grow in the mother's body. On 11 July, Gonzague Jourdain, with his Thai and French colleagues, announced that women with such drug-resistant viruses respond less well to the antiretroviral nevirapine when it is used to treat their disease later in life. The team published its work last week (Jourdain et al. New Engl.J.Med.351,229-240;2004).

South African health minister Manto Tshabalala-Msimang told delegates that her country would stop recommending nevirapine based on this evidence. Scientists called her statement misguided. A sudden ban of the drug would unnecessarily cause disease in children, they say, because no other treatment is available in most poor countries. They add that the week-long controversy has overshadowed the real importance of the work, which could save the lives of mothers and children.

"This is not the Titanic sinking, where we have to save the mother or the child," says Marc Lallemant, an author of the study from the IRD, a Paris-based research institute for sustainable development. "We are putting lifeboats all around, so everyone - mothers and children — can get out."
The women who were most affected in Jourdain's study were also the least healthy to begin with. So the lesson, says Jourdain, is that sickly mothers should be given better care before labour, which could include taking a drug in combination with nevirapine that reduces both the chance of the baby getting HIV and the chance of resistance developing in the mother. "We should improve what is in place already," says Jourdain, who works at the Harvard School of Public Health.

Another team of researchers at the conference presented similar conclusions about resistance in South African women. Infectious-disease specialist James McIntyre of the University of Witwatersrand in Johannesburg reported that if women were given nevirapine before labour and a two-drug combination therapy just afterwards, far fewer carried strains of virus resistant to nevirapine - resistance was cut at least fivefold. Jourdain called the study "preliminary, but encouraging".

In Bangkok, world health officials spoke out against Tshabalala-Msimang's stance on nevirapine. By the end of the week, the South African government had decided that although it did not recommend using nevirapine alone, it would not immediately stop dispensing it. On 14 July, the World Health Organization said that single-dose treatments should not be undermined, but alternatives should be considered where possible.

All of this spells good news for mothers and their unborn children. But many at the conference still worry about the possible effects of Tshabalala-Msimang's comments on drug policies in Africa and Asia. "The confusion our minister sows is undermining prevention programmes around the world," says activist Zackie Achmat of the South African group Treatment Action Campaign.
Stem-cell specialists split over proposal for US repository

Jonathan Knight, San Francisco

A plan to set up a national embryonic stem-cell bank in the United States has met with a decidedly mixed response. Some are calling it a political move that does nothing to address what they see as real problems with the Bush administration's policy on stem-cell research. But others hope it will prepare the National Institutes of Health (NIH) for possible future changes in policy.

The proposal, announced by Health and Human Services Secretary Tommy Thompson on 14 July, would bring all the embryonic stem-cell lines currently available to US researchers under one roof. This includes 19 current cell lines, along with a handful that are not yet ready for distribution.

Embryonic stem cells can theoretically be coaxed to generate any tissue in the body, and could one day provide treatments for diseases such as diabetes and Parkinson's. The bank would grow the cell lines in standardized conditions, aiming for uniform quality, lower costs and easier access for researchers.

"I think this is just the right kind of organization and service that the NIH should provide to the community," says Fred Gage, a stem-cell researcher at the Salk Institute for Biological Studies in La Jolla, California.

But critics point out that the bank does nothing to address the fact that there are currently so few stem-cell lines available for study. The Coalition for the Advancement of Medical Research (CAMR), a Washington-based pressure group, says the move is a worthless attempt by the Bush administration to appear active in stem-cell research. "It's a bit like giving a new paint job to a car without an engine. It's still not going to take you where you need to go," said CAMR spokesman Sean Tipton in a statement released last week.

Strangely, current distributors of stem cells do not seem to have been consulted before the announcement. Meri Firpo, who runs the distribution centre at the University of California, San Francisco, only heard the news when contacted by Nature.

And Andy Cohn, a spokesman for the WiCell Research Institute in Madison, Wisconsin, which distributes 5 of the 19 approved lines, said he did not yet know how the bank would affect his organization's work. "We don't know what the plan is," he says. 